\title{
The in vitro culture of Phytophthora infestans isolates occurring on the tomato - their pathogenicity and usefulness for artificial inoculations
}

\author{
ELŻBIETA HORODECKA
}

Research Institute of Vegetable Crops, Konstytucji 3 Maja 1/3, 96-100 Skierniewice, Poland

(Received: September 15, 1987)

Abstract

In investigations on the fungus, Phytophthora infestans, isolated from open air, field-grown tomatoes, particular attention was paid to the pathogenicity of 32 isolates and the suitability of 10 kinds of natural media. It is concluded that Phytophthora races in Poland have highly varied pathogenicities and that they belong to race 0 or 1 . The races were divided into subgroups of various aggressiveness. It was found that the best medium to obtain an inoculum was the agar-oat medium without vitamin $B_{1}$. Vitamin $B_{1}$ as well as tomatine added to agar media stimulated growth, but inhibited sporulation of Phytophthora infestans.

\section{INTRODUCTION}

In the first stage of resistance breeding, the most important problem is the isolation of the pathogene and assessment of its pathogenicity. In the case of pathogenes such as Phytophthora infestans, capable of a saprophytic way of life, the next stage is finding the best media and optimal growth conditions for in vitro culture.

THE PATHOGENICITY OF PHYTOPHTHORA INFESTANS STRAINS OCCURRING ON THE TOMATO

Phytophthora infestans belongs to a group of fungi characterized by a very high degree of variability. New races are created mainly through mutations, physiological adaptation as well as through heterokaryosis and parasexual processes. The pressure of selection also exerts an influence on the high variability of this fungus (Borecki, 1987). Studies by Sujk owski (1986) have shown the existence of periodic changes in the pathogenicity of Phytophthora infestans. This fungus probably undergoes biological cycles. During the winter it forms resting spores, while it exhibits its highest degree of pathogenicity in late spring and fall. The mechanism of Phytophthora infestans pathogenicity has not yet been completely explained. It is still unknown if this trait is recessive or dominant, as in most fungus pathogenes (Brasier, 1983). The 
increase in pathogenicity may be related to mutation or selection and adaptation of the pathogene to new nutritional substrates (Turkensteen, 1973), or too, can be dependent solely on the toxins secreted by the pathogene which affect the metabolism of the infected plant ( $\mathrm{Staples}$ and Toennissen, 1981).

The pathogenic specificity of Phytophthora infestans to tomato plants was discovered by Gallegly (1952), who also showed that two races of the fungus, $T_{0}$ and $T_{1}$ exist. The specialization of the fungus can be determined by identifying the races using test lines and varieties of tomatoes (Gallegly, 1960) or potatoes ( $\mathrm{Schick}, 1932$ ). Gallegly recommends the variety Rutgers and lines selected from Lycopersicon pimpinellifolium: West Virginia 700 and West Virginia 36-1. The fungus isolates which infect the variety Rutgers, which is classified as susceptible, but do not infect the line West Virginia 106, are classified as race 0 , while isolates which do infect it, as race 1 . The lines West Virginia 700 and West Virginia 36-1 are used to differentiate race 1 because West Virginia 36-1 has a lower degree of resistance to race 1 than West Virginia 700 . Weakly pathogenic races of fungi cause brown and dark brown spots on the leaves of susceptible tomato varieties. The daily growth of these spots is small (about $1 \mathrm{~mm}$ ), sporulation is very limited and occurs only in necrotic tissue. Strongly pathogenic races grow much more quickly (the spot increases by about $5 \mathrm{~mm}$ per day) and sporulate abundantly. On stems infected with race 0 , only small, black spots appear. Their diameter usually does not exceed $4 \mathrm{~mm}$, whereas on those infected with race 1 , large, seemingly diffuse dark greying spots, on which a patch of conidiophores is visible, can be found. Green, unripe fruits infected with race 0 have localized, dry brown spots; those infected with race 1 show evidence of systemic infection in the form of large, diffuse spots which, under favourable conditions, can be covered with a fluffy, white layer (Turkensteen, 1973).

\section{CULTURE OF THE FUNGUS UNDER LABORATORY CONDITIONS}

A pure culture of the fungus was obtained towards the end of the last century (cit. in Kubicka, 1969a). Initially, plants were used as the media, or the media were made from plant broths. Later, artificial media gelled with agar or gelatine were used. Tucker (1931) writes that at the beginning of the XXth century, Matruchot and Moliard used pumpkin pulp, while Clinton and Pethybridge, oat seeds. Oat seeds were also used by Crosier (1933), and rye, wheat, barley and corn seeds were used by Śnieszko et al. (1947), Keay (1948, 1953), Henniger (1959). Fresh potato tubers were also used as a medium (Crosier, 1933), as were dry potato leaves and stems and the seeds of legumes (de Bruyn, 1926; Keay, 1953). De Bruyn mentions that Matruchot and Moliard maintained fungus isolates in aqueous glucose solutions, Jones, Giddings and Lutman - in artificial media containing various 
inorganic components, while Kosowicz - on media with urea, guanidine, nitrates, nitrites, sucrose, dextrose and mannitol. Brasier (1983) has found that the use of glucose in media as the carbon source and the addition of vitamin $B_{1}$ significantly stimulate the growth of the fungus. In spite of the large variety of media for cultivating Phytophthora infestans, it is difficult to obtain good growth and sporulation of different isolates (Kubicka, 1969a). Contradicting opinions about the same medium are found in the literature on this subject (Crosier, 1934; Śnieszko et al., 1947; Dickins on and Keay, 1948; Gallegly, 1960; Jarmolińska-Adamczewska, 1962; Hodgson and Crainger, 1964; Kubicka, 1969a; Shirko, 1971; Laterrot, 1975; Ribeiro, 1978). French (1953) and Thurston (1957) found physiological differences among isolates of Phytophthora infestans on the basis of growth and sporulation on different media. The isolates studied by French grew and sporulated the best on bean medium, while those studied by Thurston, on pea medium. This was also noticed by Henniger (1959) when evaluating grain media for this purpose, and finding a rye broth-agar medium to be best. $\mathrm{He}$ also observed the growth of Phytophthora infestans on artificial media and found that insomuch as its growth on various natural media was better or worse, on the artificial media some of the isolates did not grow at all. Also Kubicka (1969a) found differences in growth and sporulation of various isolates both on artificial media and potato tubers and tomatoes.

Presently in the USA, Holland and France, Phytophthora infestans is cultured and reproduced most often on lima bean agar, V-8 juice agar or rye media (Ribeir o, 1978; T uit e, 1983). Totally artificial media are used less often (Wilde, 1961).

The proper temperature and lighting are important factors for growth and sporulation in vitro. The fungus can grow in a temperature range of 3 to $26^{\circ} \mathrm{C}$, but its optimum is $18-22^{\circ} \mathrm{C}$ ( $\left.\mathrm{Brasier}, 1983\right)$. The most favourable temperature for sporulation is $15^{\circ} \mathrm{C}$ according to Turkensteen (1973), while Ribeiro (1978) and Tuite (1983) report $20^{\circ} \mathrm{C}$. Light has a stronger influence on sporulation than on growth of the fungus. Some authors are of the opinion that the fungus grows better and more sporangia are formed in dispersed daylight (Brasier, 1983), others claim that darkness is more favourable (Turkensteen, 1973).

\author{
MATERIAL AND METHODS
}

ASSESSMENT OF THE PATHOGENICITY OF PHYTOPHTHORA INFESTANS RACES OCCURRING ON TOMATOES

The pathogenicity of 32 Phytophthora infestans isolates from 16 localities in Poland, 2 in Holland and 1 from the German Democratic Republic was assessed in 3 series of experiments on plants of the following tomato test lines 
used by Gallegly (1960): West Virginia 700, West Virginia 106, West Virginia 36-1. The standard of susceptibility was cv. Rutgers. The test lines were obtained from the collection of the Institute of Plant Breeding (IVT) in Wageningen (Holland). Inoculations were done in June by spraying the test plants with a suspension of spores of the studied isolate at a concentration of 50000 spores per $1 \mathrm{~cm}^{3}$. The inoculum was prepared from two-week-old cultures growing on agar media in test tubes. The sporangia were rinsed off with sterile distilled water. The suspension so obtained was incubated for $2 \mathrm{~h}$ at a temperature of $10-12^{\circ} \mathrm{C}$, after which it was transferred to room temperature for 20-30 min in order to free the zoospores. The test plants growing in greenhouses were taken to an infection cabin 3 days before the test and irradiated with $200 \mathrm{~W} / \mathrm{m}^{2}$ sodium lamps. A constant temperature of $18-20^{\circ} \mathrm{C}$ and relative humidity of $90-100 \%$ were maintained in the cabin. After inoculation the plants were securely covered with plastic foil so that darkness was maintained for $20 \mathrm{~h}$, then they were illuminated for $12 \mathrm{~h}$ per day. The evaluations were conducted after 7-10 days by visually assessing the degree of infection of each leaf using a 6 point scale where 0 - lack of infection, 5 - completely infected. On the basis of this data, the average degree of infection of leaves was calculated. Each experiment was carried out in 5 replicates each containing 10 plants.

DETERMINATION OF GROWTH AND SPORULATION OF THE FUNGUS ON ARTIFICIAL MEDIA AND SLICES OF POTATO TUBERS

The media for culturing the fungus (10) were tested in 6 series of experiments in 2-4 replicates, examining 6-12 dishes in each replicate. The preparation and sterilization of the media was done according to Tuite (1983). The $\mathrm{pH}$ of the media was brought to $5.2-5.4$ by adding citric acid. The media were gelled with agar and $20 \mathrm{~cm}^{3}$ were poured into $10 \mathrm{~cm}$ Petri dishes. The composition of the media is given only for the media modified by this author. The tested media:

1. Potato (Kiràly et al., 1977);

2. Potato with $25 \mathrm{mg}$ vitamin $\mathbf{B}_{1}$;

3. Oat: $50 \mathrm{~g}$ oatmeal, $25 \mathrm{~g}$ agar, $25 \mathrm{mg}$ vitamin $\mathrm{B}_{1}, 1000 \mathrm{~cm}^{3}$ distilled water;

4. Oat: as above without vit. $\mathbf{B}_{1}$;

5. Oat: as above with $25 \mathrm{mg}$ vit. $\mathrm{B}_{1}$ and $17 \mathrm{mg}$ tomatine;

6. Oat: as above with $25 \mathrm{mg}$ vit. $B_{1}$ and $30 \mathrm{mg}$ tomatine. Tomatine in crystalline form was obtained from the Department of Biology of the Institute of Vegetable Crops. It was dissolved in $25 \mathrm{~cm}^{3}$ of distilled water and $5 \mathrm{~cm}^{3}$ 98\% ethyl alcohol (Roddick, 1974);

7. Vegetable: juice from unripe (green) tomatoes, carrot, celery, parsley and beet roots, spinach leaves, lettuce leaves $\left(10 \mathrm{~cm}^{3}\right.$ of each), $0.75 \mathrm{~g} \mathrm{CaCO}_{3}$, $5 \mathrm{~g}$ agar, $200 \mathrm{~cm}^{3}$ distilled water; 
8. Bean: $280 \mathrm{~g}$ small seed beans, cv. Atut, $17 \mathrm{~g}$ agar, $1000 \mathrm{~cm}^{3}$ distilled water;

9. Rye (Tuite, 1983).

The studied isolates were also cultured on slices of potato cv. Bintie. Healthy tubers were washed, their surfaces sterilized with a $0.1 \%$ solution of sublimate, after which they were rinsed with sterilized water. Slices $0.5 \mathrm{~cm}$ thick were placed in sterile, $9 \mathrm{~cm}$ Petri dishes.

\section{INOCULATION AND INCUBATION OF ISOLATES}

Monospore cultures prepared according to the method used by Kubick a (1969a) were used to study the growth and sporulation of the fungus on the particular media: Two-week-old cultures were inoculated and care was taken to place equal amounts of the mycelium in the center of each Petri dish. They were incubated under the conditions of illumination and temperature given below.

\begin{tabular}{cc} 
Temperature & \multicolumn{1}{c}{ Ilumination } \\
$19^{\circ} \mathrm{C}$ & $12 \mathrm{~h}-$ dispersed light \\
& $12 \mathrm{~h}-$ darkness \\
$19^{\circ} \mathrm{C}$ & $24 \mathrm{~h}-$ darkness \\
& $12 \mathrm{~h}-$ dispersed light \\
$14^{\circ} \mathrm{C}$ & $12 \mathrm{~h}-$ darkness \\
& $24 \mathrm{~h}-$ darkness
\end{tabular}

By dispersed light we mean here daylight dimmed by gauze placed over the Petri dishes.

\section{MEASUREMENT OF MYCELIUM GROWTH AND METHODS OF COMPARISON FOR DIFFERENT MEDIA}

The first observations were recorded 4 days after inoculation by measuring the diameter of the mycelium with a ruler with an accuracy of $\pm 1 \mathrm{~mm}$. The next measurements were made every day until the fungus cultures reached the edges of the dish. The conducted measurements revealed that it could be stated with very small error that the fungus was growing proportionally to time. The graph which picture its growth is a straight line described by the equation $y=$ at, where $y$ is the mycelium diameter, $t$ time, $a$ the tangent of angle $\alpha$ formed by the intersection of the line with the $t$ axis. The line passes through the point $(0,0)$ marking the starting point of fungus growth and through the point marking the maximal diameter of the mycelium. Calculating the tangents for each dish gave a picture of the rate of mycelium growth on various media. Fourteen days after inoculation, the concentration of conidiospores was 
determined in a suspension obtained by rinsing the dishes and potato slice cultures with water. Each culture was covered with $20 \mathrm{~cm}^{3}$ of water and kept at room temperature (about $24^{\circ} \mathrm{C}$ ) for $3 \mathrm{~h}$. The suspension was then poured off and dispersed using an electromagnetic MM4 mixer for $3 \mathrm{~min}$, in order to facilitate the release of sporangia, after which it was filtered through gauze. The conidiospores were counted in Thom's chamber. The results of the experiment are presented as mean values of growth and sporulation with mean standard deviation and variance coefficient (Eland $t, 1964)$ given. The differences among the means were tested with a modified Student-Neuman-Keuls q test, which allowed uniform groups to be set up (Winer, 1962; Oktaba, Sitek, 1973). The significance of the differences was evaluated at $\alpha=0.01$.

\section{RESULTS}

THE PATHOGENICITY OF PHYTOPHTHORA INFESTANS ISOLATES FOUND ON THE TOMATO

The tested Phytophthora infestans isolates differed very much in their pathogenicity. The isolates were classified as belonging to race 0 or 1 depending on the degree of infection they caused in the individual test lines. On the basis of the $\mathrm{q}$ test, the isolates of race 0 were divided into two subgroups, while those of race 1 into three subgroups differing in their degree of aggressiveness. The subgroups were labeled with the letters a, b, c. Those isolates which caused only minimal infection of all the test lines were assigned to race $0-a ; 0-b$ included those which only slightly infected all of the test lines with the exception of cv. Rutgers, which was attacked strongly - its mean degree of infection reached 2.5. Race 1-a was composed of those isolates which only slightly attacked line West Virginia 700, slightly more West Virginia 36-1 and very strongly, causing extensive spots, West Virginia 106 and Rutgers. The isolates belonging to race 1-b strongly, systemically attacked all of the test plants, but West Virginia 36-1 the least; the degree of infection of this line approached a maximum of 2 . The most aggressive group of isolates was in race 1 -c, and infected all test plants to a degree nearing 5, causing extensive, quickly expanding spots with a sporulating mycelium. The tested isolates infected cv. Rutgers the most, West Virginia 700 the least. Only the isolates belonging to race 1-b attacked West Virginia 36-1 less than West Virginia 700. The statistical characteristics of the reaction of leaves and whole test plants to the particular Phytophthora infestans races are given in Table 1.

The degree of pathogenicity of the studied isolates turned out to be independent of their provenance. Isolates from the same locality, and even the same plantation of only one tomato variety showed extremely different pathogenicites, e.g. isolates from Reguły were classified as race 0 -a or race 1-c (Table 2). 
Table 1

Statistical characterization of the mean degree of infection of leaves of test varieties inoculated with race 0-1 of Phytophthora infestans

\begin{tabular}{|c|c|c|c|c|c|c|c|c|c|c|c|c|c|c|c|c|}
\hline & \multirow{3}{*}{ Line Variety } & \multicolumn{15}{|c|}{ Race } \\
\hline & & \multicolumn{3}{|c|}{$0-\mathrm{a}$} & \multicolumn{3}{|c|}{$0-b$} & \multicolumn{3}{|c|}{$1-\mathrm{a}$} & \multicolumn{3}{|c|}{$1-b$} & \multicolumn{3}{|c|}{$1-\mathrm{c}$} \\
\hline & & $\bar{x}$ & $\mathrm{~s}$ & $V(\%)$ & $\bar{x}$ & $\mathrm{~S}$ & $V(\%)$ & $\bar{x}$ & $\mathbf{S}$ & $V(\%)$ & $\bar{x}$ & $\mathrm{~S}$ & $V(\%)$ & $\bar{x}$ & $\mathrm{~S}$ & $V(\%)$ \\
\hline West & Virginia 700 & 0.07 & 0.14 & 194.90 & 0.24 & 0.15 & 53.49 & 0.41 & 0.25 & 62.27 & 3.59 & 0.31 & 8.71 & 4.54 & 0.54 & 12.00 \\
\hline West & Virginia $36-1$ & 0.42 & 0.36 & 50.61 & 0.76 & 0.59 & 78.64 & 1.59 & 0.42 & 26.28 & 1.93 & 0.54 & 28.03 & 4.87 & 0.24 & 4.94 \\
\hline West & Virginia 106 & 0.09 & 0.13 & 143.18 & 0.31 & 0.12 & 41.10 & 3.38 & 0.52 & 15.47 & 4.45 & 0.56 & 12.67 & 4.88 & 0.36 & 7.38 \\
\hline \multicolumn{2}{|c|}{ Rutgers } & 0.72 & 0.42 & 58.79 & 2.51 & 1.46 & 58.16 & 4.47 & 0.47 & 10.57 & 4.78 & 0.30 & 6.34 & 4.94 & 0.22 & 4.54 \\
\hline
\end{tabular}

$\bar{x}-$ mean degree of infection, $\mathrm{S}-$ standard deviation, $V$ - coefficient of variation. 
Table 2

The pathogenicity of isolates of Phytophthora infestans occurring on tomato

\begin{tabular}{|c|c|c|}
\hline $\begin{array}{l}\text { Symbol } \\
\text { of isolate }\end{array}$ & Race & Provenance of isolate \\
\hline $\begin{array}{l}\mathrm{T}_{1} \\
\mathrm{~T}_{2} \\
\mathrm{H}_{1} \\
\mathrm{H}_{2} \\
\mathrm{H}_{3} \\
\mathrm{H}_{4} \\
\mathrm{H}_{5} \\
\mathrm{E}_{1} \\
\mathrm{E}_{2} \\
\mathrm{E}_{3} \\
\mathrm{R}_{1} \\
\mathrm{R}_{2} \\
\mathrm{R}_{3}\end{array}$ & $0-\mathbf{a}$ & $\begin{array}{l}\text { Wageningen - Holland } \\
\text { Naldwijk - Holland } \\
\text { Piaseczno - near Warsaw } \\
\text { Warszawa - Warsaw } \\
\text { Przesieka - Jelenia Góra province } \\
\text { Bielsko-Biała } \\
\text { Przesieka } \\
\text { Reguły - near Warsaw } \\
\text { Powsin - near Warsaw } \\
\text { Ustrzyki Górne - Krosno province } \\
\text { Reguły } \\
\text { Reguły } \\
\text { Reguły }\end{array}$ \\
\hline $\begin{array}{l}E_{4} \\
E_{5} \\
E_{6}\end{array}$ & $0-\mathrm{b}$ & $\begin{array}{l}\text { Piaseczno } \\
\text { Konstancin - near Warsaw } \\
\text { Wolica - near Warsaw }\end{array}$ \\
\hline $\begin{array}{l}A_{1} \\
A_{2} \\
A_{3}\end{array}$ & $1-\mathfrak{a}$ & $\begin{array}{l}\text { Ulrichów - near Warsaw } \\
\text { Chąśno - Skierniewice province } \\
\text { Leszno - Poznań province }\end{array}$ \\
\hline $\begin{array}{l}\mathbf{P}_{1} \\
\mathbf{P}_{2} \\
\mathbf{P}_{3} \\
\mathbf{P}_{4}\end{array}$ & $1-b$ & $\begin{array}{l}\text { Młochów - Warsaw province } \\
\text { Konstancin } \\
\text { Warszawa } \\
\text { Quedlinburg - Germany }\end{array}$ \\
\hline $\begin{array}{l}\mathrm{C}_{1} \\
\mathrm{C}_{2} \\
\mathrm{C}_{3} \\
\mathrm{C}_{4} \\
\mathrm{C}_{5} \\
\mathrm{C}_{6} \\
\mathrm{~A}_{4} \\
\mathrm{~W}_{1} \\
\mathrm{~W}_{2}\end{array}$ & $1-\mathrm{c}$ & $\begin{array}{l}\text { Reguły } \\
\text { Leszno } \\
\text { Leszno } \\
\text { Losice - Siedlce province } \\
\text { Kazimierz } \\
\text { Wrzosowo - Koszalin province } \\
\text { Warszawa } \\
\text { Rowy - Koszalin province } \\
\text { Kozłowo - near Warsaw }\end{array}$ \\
\hline
\end{tabular}

THE USEFULNESS OF ARTIFICIAL MEDIA AND POTATO SLICES INCUBATED UNDER SPECIFIED CONDITIONS OF TEMPERATURE AND ILLUMINATION, FOR THE CULTURE OF DOMESTIC FUNGUS ISOLATES

In the conducted studies using 9 agar media and potato slices for the culture of isolates of varying degrees of pathogenicity, significant differences were revealed in the growth and sporulation of the fungi, depending on the incubation conditions, type of medium and interaction of these factors. 
The best growth of the mycelium was obtained at a temperature of $19-20^{\circ} \mathrm{C}$ and dispersed light, while at $14^{\circ} \mathrm{C}$ and darkness, growth was the weakest (Table 3 , Plate 1). More rapid growth at the higher temperature was found on each type of medium (Figs. 1 and 2). Independent of the temperature, somewhat
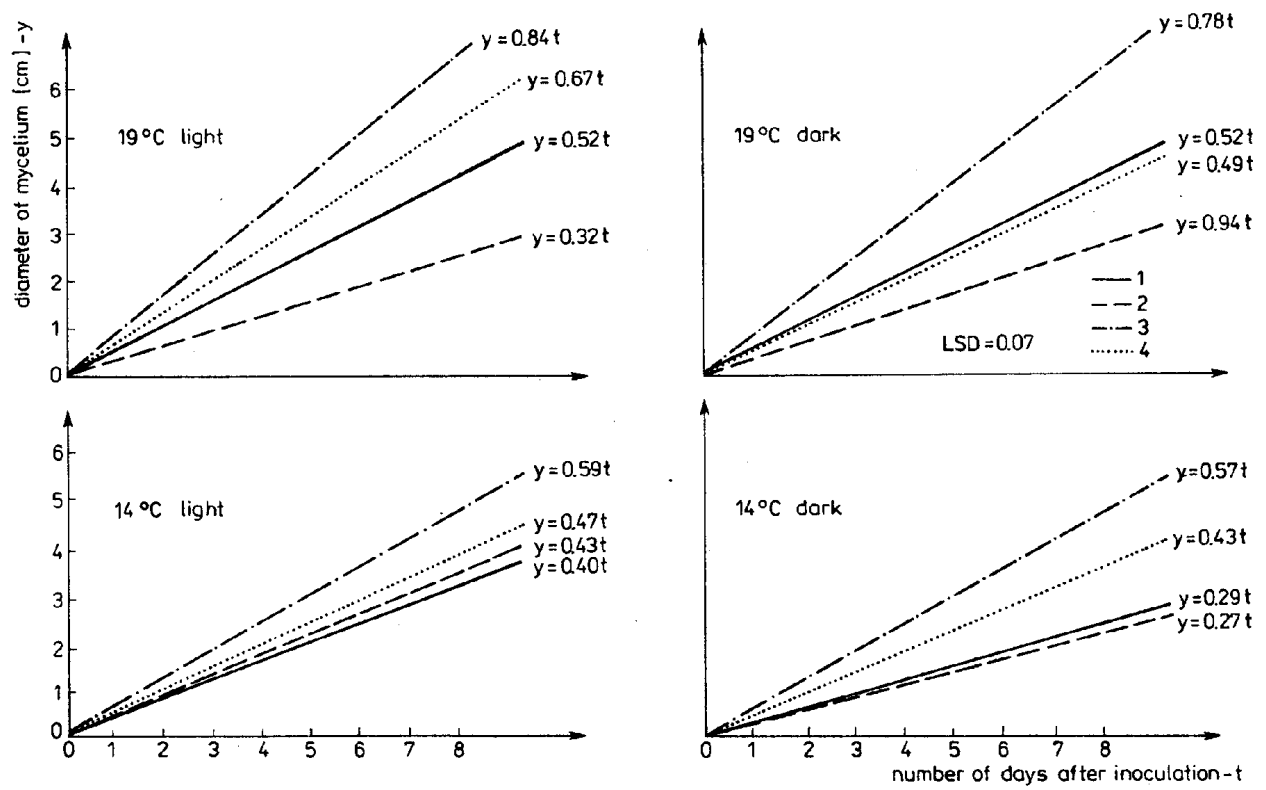

Fig. 1. Growth of mycelium on agar media under different conditions of incubation
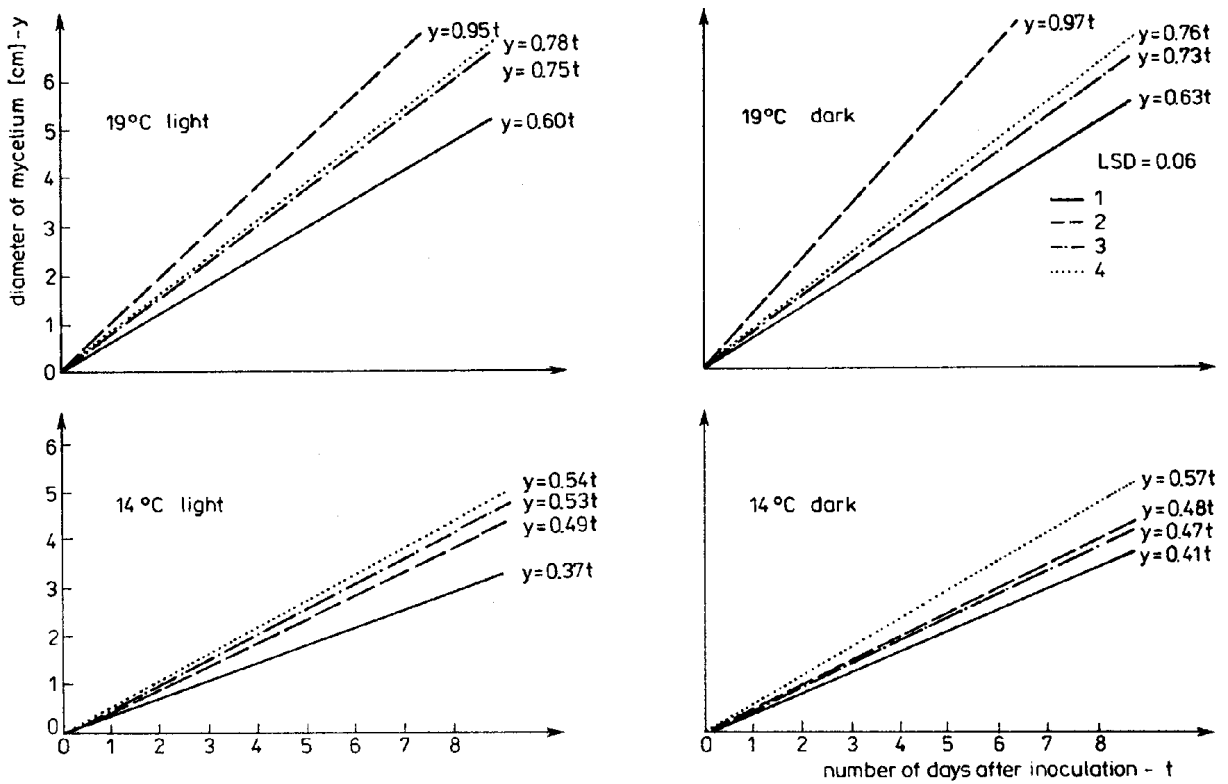

Fig. 2. Growth of mycelium on agar media under different conditions of incubation 
Plate 1

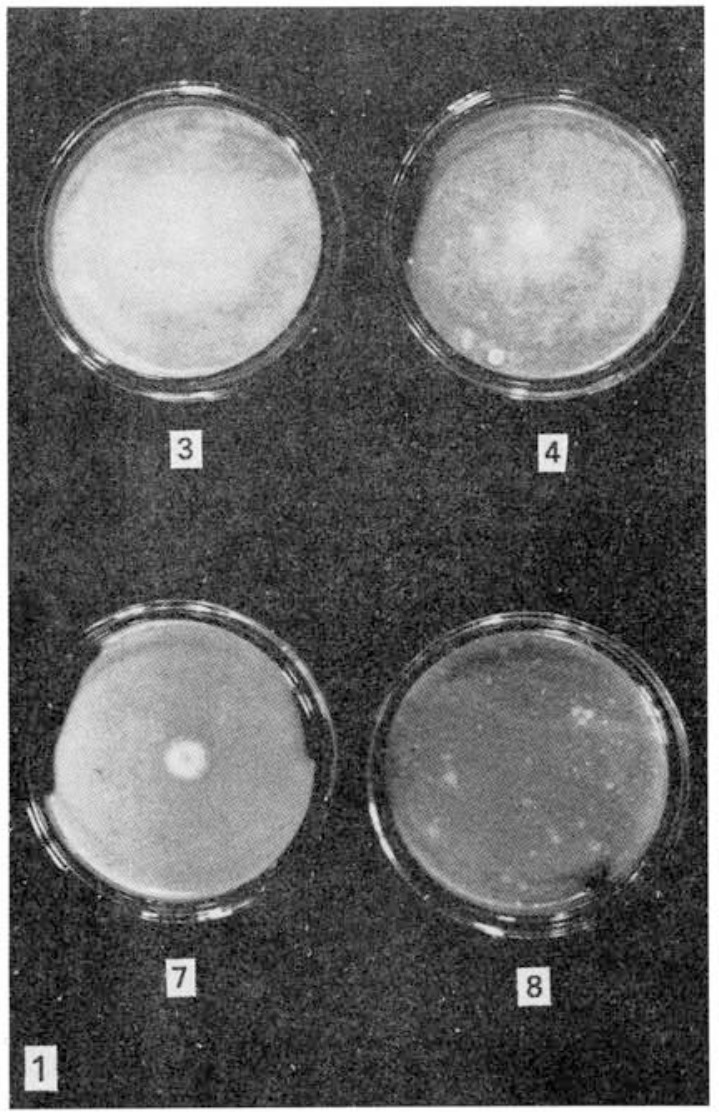

7-day-old cultures of Phytophthora infestans - race 1-c on oat agar medium Conditions of incubation:

$3-10^{\circ} \mathrm{C}$, light; $4-19^{\circ} \mathrm{C}$, dark; $7-14^{\circ} \mathrm{C}$, light; $8-14^{\circ} \mathrm{C}$, dark 
better effects, although unproven statistically (q test), were obtained in light rather than in darkness (Table 3). However, isolates were found which grew better in darkness (Plate 2). It was shown that temperature and light had a lesser effect on sporulation than on the growth of the mycelium. Sporulation was generally somewhat more abundant at the higher temperature (Table 4).

Table 3

The mean growth of the mycelium of isolates on 4 agar media under various conditions of incubation

\begin{tabular}{ccccc}
\hline No. & Incubation & $\begin{array}{c}\text { Mean growth of } \\
\text { mycelium } \operatorname{tg} \alpha\end{array}$ & $\mathrm{S}$ & $V \%$ \\
\hline 1 & $19^{\circ} \mathrm{C}$ light & 0.68 & 0.39 & 57.35 \\
2 & $19^{\circ} \mathrm{C}$ dark & 0.65 & 0.38 & 58.46 \\
3 & $14^{\circ} \mathrm{C}$ light & 0.48 & 0.33 & 68.75 \\
4 & $14^{\circ} \mathrm{C}$ dark & 0.44 & 0.33 & 75.00 \\
\hline
\end{tabular}

Test $q \quad \underline{12} \quad \underline{3 \quad 4}$,

$\mathrm{S}$ - standard deviation, $V$ - coefficient of variation.

Table 4

Mean sporulation of isolates of Phytophthora infestans under different conditions of incubation

\begin{tabular}{llc}
\hline No. & $\begin{array}{c}\text { Conditions of } \\
\text { incubation }\end{array}$ & $\begin{array}{c}\text { Number of spores } \\
\text { per } 1 \mathrm{~cm}^{3} \text { suspension }\end{array}$ \\
\hline 1 & $19^{\circ} \mathrm{C}$ light & 32462 \\
2 & $19^{\circ} \mathrm{C}$ dark & 20500 \\
3 & $14^{\circ} \mathrm{C}$ light & 9500 \\
4 & $14^{\circ} \mathrm{C}$ dark & 11012 \\
\hline Test q & 12 &
\end{tabular}

Growth of the mycelium usually began 3-4 days after inoculation. Some of the isolates grew so fast that they covered the entire surface of the dish by 7 days, others did not reach that size even after 14 days. The best growth of most of the isolates was obtained on the oat + vit. $B_{1}$ media $(\operatorname{tg} \alpha$ equalled on average 0.81 ), the poorest - on the potato media ( $\operatorname{tg} \alpha$ from $0.34-0.43$ ) (Table 5, Plate 3, phots. 1 and 2). The high variance coefficients $(88.37-105.88 \%)$ point to large differences in the growth of individual isolates on the potato media, therefore, to the low suitability of this medium. The addition of tomatine to the oat media, especially at the smaller dose $(17 \mathrm{mg})$ turned out to be advantageous (Table 5). Slices of potato tubers were shown to be little useful for culture because, with the exception of $\mathrm{C}_{3}$ and $\mathrm{C}_{4}$, the studied isolates grew very poorly or not at all on them (Table 3, Phot. 4). 


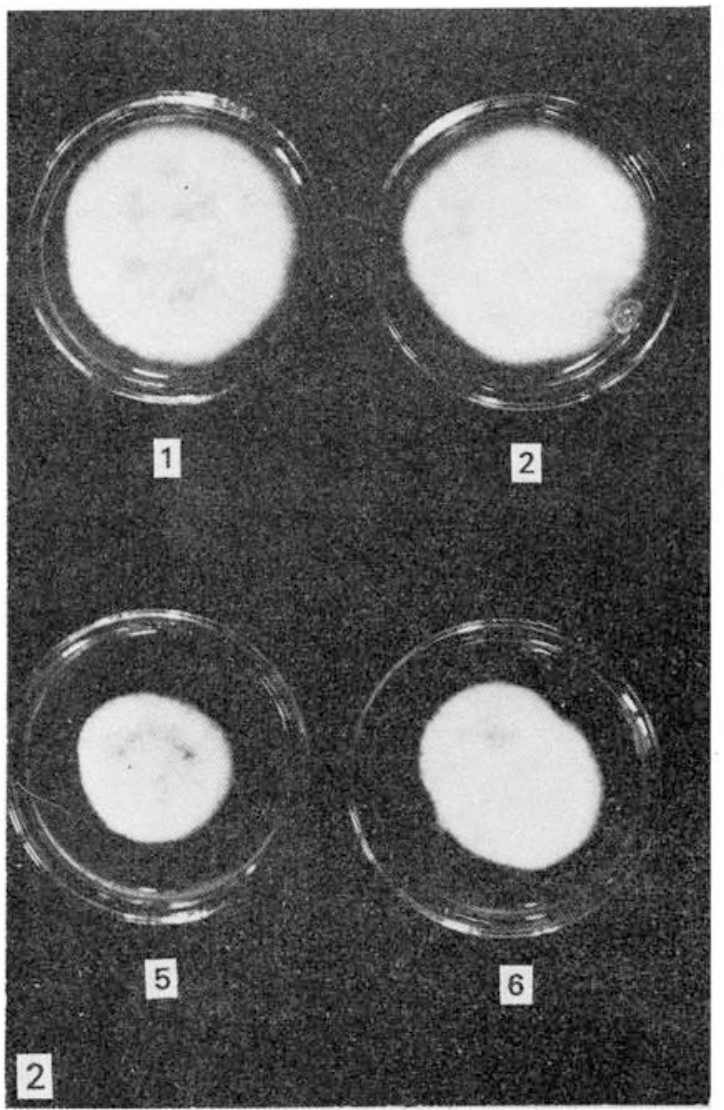

7-day-old cultures of Phytophthora infestans - isolate of race 1-c. Conditions of incubation:

$1-19^{\circ} \mathrm{C}$, light $2-19^{\circ} \mathrm{C}$, dark $5-14^{\circ} \mathrm{C}$, light $6-14^{\circ} \mathrm{C}$, dark

1. 7-day-old cultures on oat agar medium; 2. 7-day-old cultures on potato agar medium; 3 . 7-day-old cultures on potato slices of the Bintie variety Isolates:

$\mathrm{B}$ - race $1-\mathrm{b}\left(\mathrm{P}_{2}\right), \mathrm{C}-\operatorname{race} 1-\mathrm{c}\left(\mathrm{C}_{1}\right), \mathrm{D}-\operatorname{race} 1-\mathrm{c}\left(\mathrm{C}_{3}\right), \mathrm{E}$ - race 0 - a $\left(\mathrm{E}_{1}\right), \mathrm{N}$ - race $1-\mathrm{a}\left(\mathrm{A}_{3}\right), \mathrm{P}-\operatorname{race} 1-\mathrm{b}\left(\mathrm{P}_{1}\right), \mathrm{S}-\operatorname{race} 1-\mathrm{c},\left(\mathrm{C}_{4}\right), \mathrm{K}-\operatorname{race} 1-\mathrm{c}\left(\mathrm{C}_{5}\right)$ 

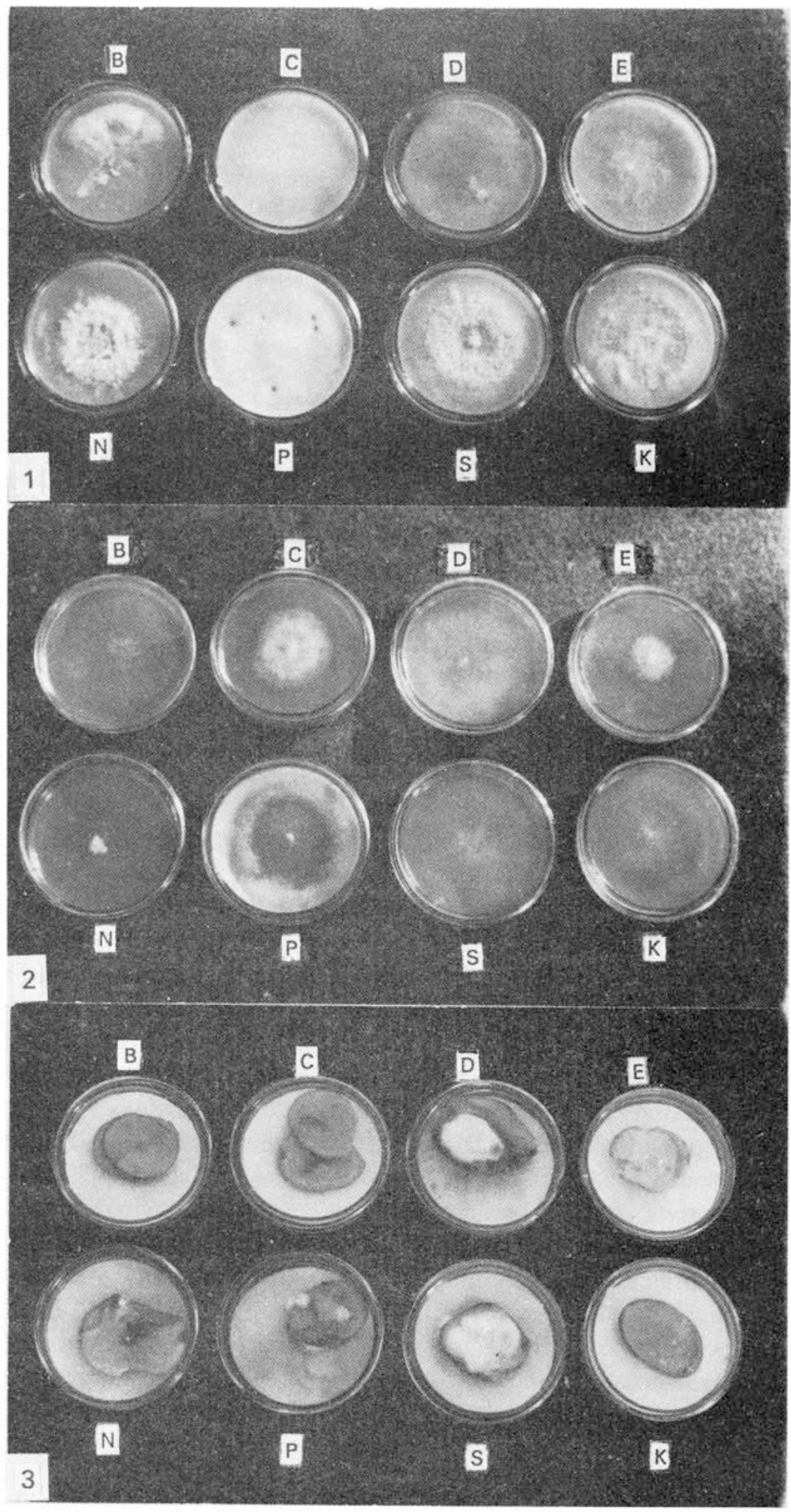
The best sporulation was achieved on the oat media, the poorest on the potato media (Table 6). The vitamin $B_{1}$ and tomatine which, added to the oat medium, clearly stimulated mycelium growth (Table 5), inhibited its sporulation.

Table 5

Mean growth of mycelium of examined isolates

\begin{tabular}{lccr}
\hline \multicolumn{1}{c}{ Medium } & $\begin{array}{c}\text { Mean } \\
\text { growth } \\
\operatorname{tg} \alpha\end{array}$ & $\mathrm{S}$ & $V \%$ \\
\hline Oat + vit. $\mathrm{B}_{1}$ & 0.81 & 0.31 & 38.27 \\
Bean & 0.78 & 0.35 & 44.87 \\
Oat + tomatine $17 \mathrm{mg}$ & 0.73 & 0.46 & 63.01 \\
Rye & 0.66 & 0.32 & 48.48 \\
Oat + tomatine $30 \mathrm{mg}$ & 0.62 & 0.38 & 61.29 \\
Oat & 0.52 & 0.34 & 65.38 \\
Vegetable & 0.51 & 0.41 & 80.39 \\
Potato + vit. B & 0.43 & 0.38 & 88.37 \\
Potato & 0.34 & 0.36 & 105.88 \\
\hline
\end{tabular}

S - standard deviation, $V$ - coefficient of variation.
Table 6

Sporulation of isolates of Phytophthora infestans on agar media

\begin{tabular}{lc}
\hline \multicolumn{1}{c}{ Medium } & $\begin{array}{c}\text { Number of } \\
\text { spores per } 1 \mathrm{~cm}^{3} \\
\text { suspension }\end{array}$ \\
\hline Oat & 40027 \\
Oat + vit. B $_{1}$ & 29175 \\
Oat + tomatine $30 \mathrm{mg}$ & 19500 \\
Oat + tomatine $17 \mathrm{mg}$ & 13500 \\
Rye & 8758 \\
Bean & 8400 \\
Potato & 7330 \\
Vegetable & 5000 \\
Potato + vit. B $_{1}$ & 977 \\
\hline
\end{tabular}

\section{DISCUSSION}

The results of the experiments presented in this report indicate that the Phytophthora infestans races found in Poland are highly differentiated in respect to their pathogenicity. They were classified as belonging to either race 0 or 1 , in accordance with the criteria set by Gallegly (1960). It was seen, however, that the reaction of the test plants to a given race was not uniform. Groups of isolates of varying aggressiveness were distinguished within one race. Similar differentiation of the races occurring in Poland was observed by Kubick a (1969b). The exception was the race denoted as 1-b. It showed a different reaction than that described by Gallegly (1960) and Kubicka (1969b). It infected West Virginia - the resistance standard - more strongly than West Virginia 36-1, usually the less resistant line in this test set. This may point to the occurrence of a new group of races which react differently from those known until now. They probably have additional virulence genes, different from those of the remainder of the isolates belonging to race 1 and due to which they prefer West Virginia 700 as their host. It is also possible that West Virginia 36-1 has genes of partial resistance which differ from those of West Virginia 700, by which it may be a less suitable host for this group of isolates. In the process of breeding the fungus, many difficulties were found in obtaining good growth and sporulation of the various isolates on artificial media. Relatively good growth and sporulation were attained on oat media, 
also recommended by Galle gly (1960), Kubick a (1969a). Shirk o (1971) and Laterrot (1975). The composition of the media used by the above-named authors was similar to that used in this study, except that in order to facilitate the preparation of the media, oatmeal was used instead of oat mash. The addition of vit. $B_{1}$ proposed by Brasier (1983) did have a favourable effect, but only on the growth of the mycelium; it clearly inhibited its sporulation, the basic requirement for obtaining an inoculum. The media proposed by other authors and those modified by this author were shown to be less suitable for culturing this fungus. The poorest growth and sporulation were observed on the potato medium. The rye medium, considered the best by Ribeiro (1978) and Tuite (1983), was better than the potato, but much less satisfactory than the oat medium. The addition of tomatine to the oat medium enhanced growth, but inhibited sporulation of the mycelium. Zhucenko et al. (1975) using similar doses of tomatine found that it had a slightly stimulatory or slightly fungistatic effect on in vitro mycelium growth. The effect of that compound seen in this study, however, was greater than reported above. The explanation of this effect given by those authors that different tomatine fractions were active in different experimental series does not seem to hold in the light of the results of this study. It seems, rather, that those differences were due more to the use of different fungus isolates than to the activity of various fractions of tomatine, since the tomatine used in the experiments presented here contained all of its fractions. It may be that the isolates collected in Poland were resistant to tomatine in vitro. It is also possible that tomatine does not act fungistatically directly, but acts in plant juices where it modifies the plant's enzymic reactions, indirectly inhibiting the growth of the fungus. From the observations on the growth and sporulation of Phytophthora infestans on the media containing tomatine it can be concluded that a more important indicator of the effect of this glycoalkaloid on the pathogene is sporulation.

The results of this study dealing with the growth and sporulation of Phytophthora infestans under varying conditions of incubation did not confirm the results of Turkensteen's work (1973), but were in agreement with the recommendations of Ribeiro (1978) and Tuite (1983) and showed that most of the strains grew better at $19^{\circ} \mathrm{C}$. The effect of light and temperature on sporulation was shown to be slight; it was a bit more abundant under dispersed daylight and higher temperature. Brasier (1983) reports that these factors have a greater influence on the sporulation of the fungus than on its growth. In contrast to Turkensteen (1973), he also claims that light is better for sporulation than darkness.

\section{REFERENCES}

Borecki Z., 1987. Nauka o chorobach roślin. PWRiL, Warszawa.

Brasier C. M., 1983. Problems and prospects in Phytophthora research. Phytophthora. Its biology, taxonomy, ecology and pathology. The Am. Phytopath. Soc., St. Paul, Minnesota. 
Bruyn H. L. G., de, 1926. The overwintering of Phytophthora infestans (Mont.) de By. Phytopathology, 16: 340-359.

Crosier W., 1933. Culture of Phytophthora infestans. Phytopathology, 23: 713.

Crosier W., 1934. Studies in the biology of Phytophthora infestans (Mont.) de Bary. Memoir of the Cornell Univ. Agr. Ex. St. Ithaca, New York, 155: 1-40.

Dickinson S., Kea y M. A., 1948. Growth of Phytophthora infestans (Mont.) de Bary on artificial media. Nature, 162: 32.

Elandt R., 1964. Statystyka matematyczna w zastosowaniu do doświadczalnictwa rolniczego. PWN, Warszawa.

French A. M., 1953. Physiologic differences between two physiologic races of Phytophthora infestans. Phytopathology, 43: 513-516.

Gallegly M. E., 1952. Physiologic races of the tomato late blight fungus. Phytopathology, 42: 461-462.

Gallegly M. E., 1960. Resistance to the blight fungus in tomato. Proc. Plant Sci. Seminar, Campbell Soup Co. 113-135.

Henniger H., 1959. Versuche zur Kultur verschiedener Rassen von Phytophthora infestans (Mont.) de Bary auf künstlichen Nährböden. Phytopath. Z. 34: 285-306.

Hodgson W. A., Grainger P. N., 1964. Culture of Phytophthora infestans on artificial media prepared from rye seeds. Can. J. Pl. Sci. 44: 583.

Jarmolinska-Adamczewska H., 1962. Studies of the methods of cultivation of Phytophthora infestans (Mont.) de Bary. Bull. Acad. Pol.. Sci. Ser. Biol. 10: 261-262.

Keay M. A., 1948. Growth of Phytophthora infestans (Mont.) de By on artificial media. Nature, 162: 162 .

Keay M. A., 1953. Media for the culture of Phytophthora infestans. Plant Pathology, 2: 16-17.

Kiràly Z., Klement Z., Solymosy F., Vörös J., 1977. Fitopatologia. Wybór metod badawczych. PWRiL, Warszawa.

Kubick a H., 1969a. Badania nad Phytophthora infestans (Mont.) de By na pomidorach w Polsce. Obserwacje nad wzrostem i zarodnikowaniem $P h$. infestans na różnych podłożach oraz nad morfologią i biologią zarodników konidialnych. Acta Agrobot. 22: 147-164.

Kubick a H., 1969b. Badania nad Phytophthora infestans (Mont.) de By na pomidorach w Polsce. Porównawcze badania nad patogenicznością szczepów Phytophthora infestans z pomidorów oraz próba identyfikacji ras tego grzyba. Acta Agrobot. 22: 281-301.

Laterrot H., 1975. Sèlèction pour la rèsistance au mildiou Phytophthora infestans (Mont.) de Bary chez la tomate. Ann. Amèlior. Plantes, 25: 129-149.

Oktaba N., 1966. Elementy statystyki matematycznej i metodyka doświadczalnictwa. PWN, Warszawa.

Ribeiro D. K., 1978. A source book of the genus Phytophthora. California, USA.

Roddick J. G., 1974. The sterioidal glycoalkaloid: $\alpha$-tomatine. Phytochemistry, 13: 9-25.

Schick R., 1932. Über das Verhalten von Solanum demissum, Solanum tuberosum und ihren Bastarden gegenüber verschiedenen Herkünften von Phytophthora infestans. Der Züchter, 4: 233-237.

Shirk o V. N., 1971. O metodach izucheniya ustojchivosti tomatov k fitoftore. Trudy Prikl. Bot. Gen. Sel. 43: 161-167.

Sitek M., 1973. Testy porównań wielokrotnych. Listy biometryczne Pol. Tow. Biometryczne, Wrocław, 39-41.

Staples R. C., Toenniessen G. H., 1981. Plant disease control. Resistance and susceptibility. John Wiley and Sons, New York.

Sujk owski L. S., 1986. Seasonal variation in pathogenicity of Phytophthora infestans. Phytopathology, 117: 160-172.

Śnieszko S. F., Carpenter J. B., Lowe E. P., Jakob J. G., 1947. Improved methods for the cultivation and storage of Phytophthora infestans. Phytopathology, 37: 635-649. 
Thurston H. D., 1957. The culture of Phytophthora infestans. Phytopathology, 47: 186. Tucker C. M., 1931. Taxonomy of the genus Phytophthora de Bary. Columbia, Missouri. Tuite J., 1983. Plant pathological methods. Fungi and bacteria. Burgess Publ. Com., Minneapolis. Turkensteen L. J., 1973. Partial resistance of tomatoes against Phytophthora infestans, the late blight fungus. Ph. D. Thesis, Institute of Phytopathological Research, Wageningen.

Wilde P., 1961. Ein Beitrag zur Kenntnis der Variabilität von Phytophthora infestans (Mont.) de Bary. Arch. Mikrobiol. 40: 163-195.

Winer B. J., 1962. Statistical principles in experimental design. Mc Graw Hill, New York. Zhuchenko A. A., Balashova N. N., Andryushchenko V. K., 1975. O roli glikoalkaloida $\alpha$-tomatina $\mathrm{v}$ ustojchivosti tomatov $\mathrm{k}$ boleznyam i vreditelyam. Sel'khoz. Biol. 3: 451-452.

Hodowla in vitro izolatów Phytophthora infestans występujących na pomidorze - określenie ich patogeniczności i przydatności do sztucznych zakażeń

\section{Streszczenic}

Celem pracy było rozpoznanie krajowych ras Phytophthora infestans występujących na pomidorach polowych oraz określenie najlepszych podłoży i warunków dla dobrego wzrostu i zarodnikowania grzyba in vitro. Określano patogeniczność 32 izolatów i 10 rodzajów podłoży dla dobrego wzrostu i zarodnikowania grzyba. Stwierdzono, że rasy Phytophthora infestans w Polsce są silnie zróżnicowane pod względem patogeniczności i należą do rasy 0 lub 1. W obrębie każdej rasy wydzielono grupy izolatów różniących się stopniem agresywności. Rasę 0 podzielono na 2, a rasę 1 na 3 podgrupy. Znaleziono także nową grupę izolatów o silnej patogeniczności oznaczając ją jako 1-b, która różni się od opisanych dotychczas w literaturze fitopatologicznej. Ustalono, że najlepszą pożywką dla wzrostu grzyba jest pożywka agarowa $\mathrm{z}$ płatków owsianych $\mathrm{z}$ witaminą $\mathrm{B}_{1}$. Najprzydatniejszą pożywką dla uzyskania inokulum jest pożywka agarowo-owsiana bez witaminy $B_{1}$. Stwierdzono, że tomatyna dodana do pożywek agarowych stymuluje wzrost, a hamuje zarodnikowanie Phytophthora infestans. 